\title{
An Analysis of Students' Grammatical Errors in Arranging Jumbled Words into Meaningful Sentences of the Einght Grade at SMP Negeri 4 Banyuwangi in the Academic Year 2016/2017
}

\author{
Dilla Ayuning Pangestu \\ Prodi Bahasa Inggris, Fakultas Bahasa dan Seni, Universitas PGRI \\ Banyuwangi
}

Received : Tuesday, March 6, 2018

Revised : Monday, March 12, 2018

Accepted : Tuesday, March 27, 2018

\begin{abstract}
Writing cannot be separated from sentences. Constructing sentences is a start to write a composition since it has levels of difficulties starting from words to sentences, sentences to paragraph and paragraph to longer composition. Jumbled words is a method of teaching. There are some words or sentences which are jumbled by teacher and the students must arrange them into correct sentences. This research is a descriptive quantitative one that focused on the data analysis with form description with the scoring of the eight grade students' grammatical errors in arranging jumbled words into meaningful sentences at SMP Negeri 4
\end{abstract}

Banyuwangi in the Academic Year 2016/2017. Purposive method was used to determine the research area. The number of respondent were 30 students. The result of the data analysis showed that compose sentences was difficult for the eight year students of SMP Negeri 4 Banyuwangi. (1) There are 126 miordering of using adjective followed by noun with the percentage $23,37 \%$.

(2) There are 46 misordering of using verb followed by

adverb with the percentage 8,53\%. (3) There are 98 misordering of using auxiliary verb ( do, do es and did)

with the percentage 18,18\%, (4) There are 95 misordering of using to be past tense (was and were) with the percentage $17,62 \%$. (5) There are75 misordering of using Simple Present Tense with the percentage 13,91\%. (6) There are 99 misordering of using Simple Past Tense with the percentage $18,36 \%$

Keywords:writing; jumbled words; descriptive quantitative

\section{A. Introduction}

English as a foreign language in Indonesia has influenced many aspects of life, including therefore the educational aspect. English is determined as a compulsory school subject in the national curriculum. One of the problems in studying english is understanding grammar. Grammar problem occured is error in arranging some words into a good and meaningful sentences. errors are considered as the inevitable 
consequences of language learning. They are in fact part of a learning process and may provide valuable insight into the language learning process. This, error analysis of a language will lead to the analysis of grammatical errors. the researcher is eager to know the difficulties in arranging jumbled words. the researcher is eager to do a research with entitled "An Analysis of Students' Grammatical Errors in Arranging Jumbled Words into Meaningful Sentences of the Eighth Grade at SMP Negeri 4 Banyuwangi in the Academic Year 2016/2017.

\section{B. Research Method}

In this research, the researcher analyzed the students' grammatical errors in arranging jumbled words into meaningful sentences of the eight grade at SMP Negeri 4 Banyuwangi. Therefore the research design which matches with this resarch is descriptive quantitative where the results of this research are in form of description and score. Purposive method is used to select the research area based on specific purpose. SMP Negeri 4 Banyuwangi is selected as the research location because many students at SMP Negeri 4 Banyuwangi don't have capacity in writing mainly arranging jumbled words into sentences. Respondents in this research are the eighth grade SMP Negeri 4 Banyuwangi.

In this research the researcher used Cluster Random Sampling in determining the respondent where each students have a chance to be respondent in this research, but the researcher only take some students to be respondent in this research. In each class there are 30 students. Two classes are determined as the research samples, because they are homogeneous. Finally, VIIIB class and VIIIE class students are chosen as the respondents of this research. Therefore, the researcher used lottery in selecting sample respondent. First the researcher prepare 30 lottery. On each paper, the researcher fill only 15 pictures. Only 15 students from each class who got the pictorial paper be respondents in this research.

Test is a way of discovering, by questions or practical activities, what someone knows or someone can do. The researcher wanted to know the students' ability in an arranging jumbled words in structure of modification (adjective folowed by noun and verb followed by adverb), auxiliary verb and to be (auxiliary verb (do, does and did) and to be Past tense(was and were) and particular tenses (Simple Present Tense and Past Tense). The focus is sentence structure of simple sentences. The teacher analyzed the data resulted from the student's writing test. The researcher followed the following steps:

1. Distribute question paper with 40 questions of jumbled words to the students.

2. Tell the students they are going to arrange words to make meaningful sentence.

3. When the students finished their work, they submit the answer sheets to the researcher. 
The interview exists in a variety of forms ranging from formal interviews, for example, conducted in surveys, through the internet, over the telephone, or in face-to-face interaction, to more informal conversations conducted for research purposes. The researcher conducted an interview with english teacher in the teacher's room after writing test. The researcher used the mother tongue or Indonesian language in order to avoid misunderstanding and misinterpreting between the researcher and the teachers.

The researcher followed the following steps:

1. The researcher read some questions.

2. The teacher answer the question.

3. The researcher wrote the teachers' answer in a note.

The research data were analyzed by descriptive quantitative formula to calculate the students' grammatical errors in arranging jumbled words into meaningful sentences of the eight grade at SMPN 4 Banyuwangi in the Academic Year 2016/2017.

\section{The Result of The Research}

After collecting the data from the test, the researcher found some errors made by students. They are:

1. Misordering of using adjective followed by noun

2. Misordering of using verb followed by adverb

3. Misordering of using auxiliary verb (do, does and did)

4. Misordering of using to be Past Tense (was and were)

5. Misordering of using Simple Present Tense

6. Misordering of using Simple Past Tense

The data processing are taken from students' writing test. Then, the researcher classified the students' grammatical errors in arranging jumbled words into meaningful sentences test. In this case, the researcher only focused on misordering of using adjective followed by noun, misordering of using verb followed by adverb, misordering of using auxiliary verb (do,does and did), misordering of using to be past tense (was and were), misordering of using simple Present Tense and misordering of using Simple Past Tense.

The researcher made a written test for students of SMP Negeri 4 Banyuwangi total forty (40) items. The students' grammatical errors it can be stated that

1. Total errors of adjective followed by noun are 126 errors on percentage $23,35 \%$

2. Total errors of verb followed by adverb are 46 errors on percentage $8,53 \%$

3. Total errors of auxiliary verb (do,does and did) are 98 errors on percentage $18,18 \%$

4. Total errors of to be past tense (was and were) are 95 errors on percentage $17,62 \%$

5. Total errors of simple present tense are 75 errors on percentage 13,91 $\%$

6. Total errors of simple past tense are 99 errors on percentage $18,36 \%$ 


\section{Conclusion}

The present study was intended to answer the following research questions: what grammatical errors made by students in arranging jumbled words and what types of grammatical errors made by students in arranging jumbled words. The main data required to answer this research question were taken from writing test and interview.

The result of the data analysis clearly showed that: (1) There were 126 misordering of using adjective followed by noun with the percentage $23,37 \%$. (2) There were 46 misordering of using verb followed by adverb with the percentage $8,53 \%$. (3) There were 98 misordering of using auxiliary verbs with the percentage

$18,18 \%$. (4) There were 95 misordering of using to past tense was, were with the percentage $17,62 \%$. (5) There were 75 misordering of using simple present tense with the percentage 13,91\%. (6) There were 99 misordering of using simple past tense with the percentage $18,36 \%$.

In general these findings suggest that the degrees of the acquisition of some arranging the jumbled words into meaningful sentences by the eighth students at SMPN Negeri 4 Banyuwangi in the Academic Year 2016/2017 are satisfied. Seeing the facts, the researcher infer that the last result of respondent are good category.

Referring to the significances of the establishment of the present research findings, the following are some suggestions:

1. The English teacher at SMPN 4 Banyuwangi prepare their teaching materials by considering the universal strong pedagogical implications of the sentence form theories. That is, they should give more serious attention and emphasis to the teaching of adjective followed by noun, verb followed by adverb form, auxiliary verbs (do,does and did), to be past tense (was and were), Simple Present Tense, Simple Past Tense. Indeed, profesional teachers should keep on reading books thereby enabling themselves to be more effective and efficient in their teaching. It is actually hard to imagine how English teacher could undertake and manage teaching learning process successfully in case by lack relevant working theories.

2. The eighth grade students of SMPN 4 Banyuwangi in the Academic Year 2016/2017 are also suggested to be more motivated and industrious in their learning of English mainly in arranging the jumbled words into meaningful sentences. Studies have widely recognized and remarked that the learners' motivation is of paramount importance in determining their success or failure in learning English in foreign language settings.

\section{E. Acknowledgement}

The researcher would like to thanks to my greatest advisors Wulan Wangi, M.Pd and Wiwin Indiarti, S.S., M.Hum who have guided me with care, patient, and allow me to profit from their advice in writing the thesis. The researcher also thanks to the following peoples: 
1. Drs. H. Teguh Sumarno, MM, as the rector of PGRI University of Banyuwangi2. Abdul Munir, M.Pd, as the Dean of the Language and Art Faculty of PGRI University of Banyuwangi

2. Wulan Wangi, M.Pd, as the Head of English Education Department of PGRI University of Banyuwangi

3. All of my Family who always support me, thank you so much

4. All of my lectures and staffs of English Education Department of PGRI University Banyuwangi

5. All of my friends at PGRI University of Banyuwangi, especially from English Education Department

\section{F. References}

[1]Andersen. S. 2014. Sentence Types and Functions. San José State University Writing Center.

[2]Arba'in, Muhammad.2011.Improving Students' Simple Present Tense Mastery through Task- Based. Salatiga: English Education Department of State Institute of Islamic Studies (STAIN).

[3]Brinkmann.Svend.2014. Encyclopedia of Critical Psychology.Denmar : Springer New York.

[4]Dulay. 1992. Language Two. New york: University of oxford

[5] Hotman. C. Robert. 1992. Manual on Descriptive Analysis Testing for Sensory Evaluation. American: Astm Manual Series.

[6] Joseph. 2003. Collage of Education Writing Studio.

[7] Kothari. C. R. 2004. Research Methodology Methods and Techniques (Second Revised Edition). Jaipur (India): New Age International Ltd.

[8] Mart. Tugrul Cagri. 2013. Theory and Practice in Language Studies. Finland:Academy Publisher.

[9] Robbins. Lara. 2007. Grammar and Style at Your Fingertips.

[10] Sarbadani. Faizah. 2013. Improving Students' Vocabulary by Using Jumbled Words at the Fifth Grade Students of SD N 03 Mojoandong Boyolali in 2011/2012 Academic Year:School of Teacher Training and Education Muhammadiyah University of Surakarta.

[11] Setianingsih Tutus. 2016. A Descriptive Study of Errors in the Use of English Articles in Writing Made by the Seventh Year Students of SMPN 4 ROGOJAMPI SATU ATAP in the Academic Year 2015/2016: English Education Department Languge And Art Faculty PGRI University of Banyuwangi. 
[12] Setyawan Harits. 2012. Analysis of Students' Errors in Using Correlative Conjunction at the Third Year Students of SMP Karya Bakti Gadingrejo based on Surface Strategy And Communicative Effect Taxonomies. University of Lampung.

[13]Wageyono. 2001. The Acquisition of Structures of Modification by the Second Year Students of SLTP 10 Denpasar. English Department Faculty of Teacher Training And Education Mahasaraswati University at Denpasar 2001.

[14] Yogatama. 2017. Learning to Compose Words into Sentences with Reinforcement Learning. University of Oxford: Published as a conference paper at ICLR 2017. 